\title{
Different Responses of Echinochloa crus-galli and Echinochloa colona to Bisbyric-sodium (Nominee ${ }^{\mathrm{tm}}$ )
}

\author{
Abdel-hamid A. Khedr", Mamdouh S. Serag, Heba E. Shaaban and Gaber M. \\ Abogadallah \\ Department of Botany \& Micribiology, Faculty of Science, Damietta University, New \\ Damietta, Egypt.
}

\begin{abstract}
$\boldsymbol{E}$ CHINOCHLOA crus-galli and Echinochloa colona mostly grown as weeds in different economic crops and cause losses in their yield. Flooding and crop rotation can not suppress these weeds. Herbicides are widely applied to control barnyard grasses. Bisbyricsodium was applied at FRD (Field Recommended Dose) on both species, the results of preliminary experiment indicated that E. crus-galli was susceptible to bispyribac-sodium but $E$. colona was resistance. The confirmation experiment for $E$. colona resistance indicated that herbicide effect on the biomass of plants which caused reduction in fresh and dry weight. The photosynthetic pigments were affected by herbicide, which decreased by increasing the herbicide concentration. While anthocyanins content were increased to protect the leaves from the stress of photoinhibitory light fluxes by absorbing the excess photons. The soluble and insoluble sugar content was increased by increasing the concentration of herbicide. The transcript level of $A L S$ in E. colona was modified by different concentrations of herbicide. The present study indicated that $A L S$ expression level was responsive to herbicide treatment. This suggests that $A L S$ is a target site of bispyric-sodium. But $50 \%$ FRD can be considered as sublethal dose which upregulated the expression of $A L S$ by 4 folds.
\end{abstract}

Keywords: ALS, Echinochloa, Herbicide, Anthocyanine.

\section{Introduction}

The genus Echinochloa includes serious weeds in agriculture being the third and fourth most important weeds in the world (Holm et al., 1977). Echinochloa colona, a vigorous C4 annual species, is one of the world's most serious grass weeds in rice (Holm et al., 1991 and Rao et al., 2007). More than 60 countries have reported it as a weed problem in 35 crops, including rice (Oyza sativa), maize (Zea mays L.), sorghum (Sorghum bicolor L.), sugarcane (Saccharum officinarum L.), cotton (Gossypium hirsutum L.), and peanuts (Arachis hypogea L.) (Holm et al., 1991). This weed has been reported to occur in 24 countries in dry-seeded rice, in 12 countries in wet-seeded rice, and also in transplanted rice (Rao et al., 2007). E. colona is an example of crop mimicry because it closely resembles rice at the seedling stage and is sometimes unintentionally transplanted into fields together with the crop. Echinochloa crus-galli (L.) Beauv is a C4 weed that grows essentially in paddy fields, well known weed of this genus and is distributed worldwide. Yield losses caused by Echinochloa sp. invasion in rice can be very severe and variable in relation to the cultivar and the duration of competition.

The importance of Echinochloa species in rice is increasing and this is due to the development of resistance to herbicides in several populations. Within the major herbicides applied in rice, resistances have been reported to bispyribacsodium, cyhalofop-butyl, molinate, propanil, and quinclorac (Fischer et al., 2000 and Busi et al., 2002).Several management practices, including intensive chemical control, are used to reduce $E$. crus-galli infestation in rice production systems in many countries (Gibson et al., 2003 and Hoagland et al., 2004). Intensive herbicide used on E. colona and E. crus-galli has already led to the evolution of herbicide resistance to propanil, quinclorac, azimsulfuron, and fenoxaprop-p-ethyl (Rao et al., 2007).

Bispyribac-sodium, sodium 2, 6-bis [(4, 6-dimethoxy-2-pyrimidinyl) oxy] benzoate, is an herbicide used for rice farming. It is indicated for the post-emergence control of cyperaceous grasses and some dicotyledonous grasses 
and is sold commercially as a suspension concentrate under the name of Nominee. The herbicides bispyribac-sodium, penoxsulam and imazamox are acetolactate synthase (ALS; EC 2.2.1.6)-inhibiting herbicides and have a propensity rapidly to select for resistant weed accessions (Tranel \& Wright, 2002). This is confirmed by the fact that 126 weed species have already developed resistant accessions to ALSinhibiting herbicides (Tranel et al., 2012). In most cases, resistance is due to point mutations in one of the following codons: Ala122, Pro197, Ala205, Asp376, Arg377, Trp574, Ser653 and Gly654, numbered on the basis of the sequence of Arabidopsis thaliana (L.) Heyhn (Tranel et al., 2012). In most cases, resistance to ALS-inhibiting herbicides is caused by an altered ALS enzyme (Tranel \& Wright, 2002).

Acetolactate synthase (ALS, EC 2.2.1.6; also referred to as acetohydroxyacid synthase) is the first common enzyme in the biosynthetic pathways leading to the branched-chain amino acids (isoleucine, leucine, and valine). ALS does not exist in mammals, and thus ALS-inhibiting herbicides are thought to be less toxic to mammals. Resistance to ALS-inhibiting herbicides in plants has in most cases been conferred by either single or double amino acid substitutions at a particular position in ALS (Kawai et al., 2007 and Okuzaki et al., 2007). ALS-inhibiting herbicides have become widely used in world agriculture. Consequently, there has been evolution of many $A L S$ herbicideresistant weed populations, with resistant biotypes of 110 weed species worldwide (Heap, 2011).

The knowledge of the response of Echinochloa populations to different herbicides may have several implications. This information, when coupled with the knowledge of the Echinochloa population structure at field or regional scale, is fundamental for the elaboration of appropriate weed management strategies, including the development of models capable to predict the overall weed control level achievable with a certain herbicide.

\section{Materials and Methods}

\section{Preliminary experiment}

Investigation the response of E. crus-galli and E. colona to Bispyribac-sodium (Nominee ${ }^{\mathrm{tm}}$ $0.015 \%$ ) herbicide

\section{Experimental design}

The seeds of the two species E. crus-galli and E. colona were sown in a green house in June
2012. Greenhouse conditions were: $1550 \mu$ mole m-2 s-1 maximum light intensity, $28 / 19^{\circ} \mathrm{C}$ day/ night temperature, $14 \mathrm{~h}$ photoperiod, $70 \%$ relative humidity, $4.97 \mathrm{~m} \mathrm{~s}-1$ wind speed. After one month, 10 seedlings of each species were transplanted into blocks $50 \times 50 \mathrm{~cm}$. The experimental design was a randomized complete block design with 3 replicates, 12 blocks represent all treatments 20 plants in each block (10 E. crus-galli and 10 E. colona). After 10 days of transplanting, the plants were treated with $50 \%, 100 \%$ and $200 \%$ field recommended dose (FRD) of nominee. The herbicide applications were made using sprayer. Nitrogen fertilizer was applied as urea (50 gm / Sq.m.)one week before herbicide application. The herbicide treatment was carried out as recommended by the manufacturer.

\section{Harvesting of the plants}

Seven days after treatment with herbicide, the plantswere collected, placed in paper envelops and oven-dried at $65^{\circ} \mathrm{C}$ for $48 \mathrm{~h}$.

\section{Biomass yield}

Determination of fresh and dry weights and water contents: After recording the fresh weights of shoots, they were dried in oven at $80^{\circ} \mathrm{C}$ for 2 days and the dry weights were then recorded. The water contents were calculated on fresh weight basis. Three plant replicates were used for each treatment.

\section{Confirmation experiment}

The resistance of E. colona to Nominee

Seeds of $E$. colona were planted in the green house in July 2012. Greenhouse conditions were: $1550 \mu$ mole m-2 s-1 maximum light intensity, $28 / 19^{\circ} \mathrm{C}$ day/night temperature, $14 \mathrm{~h}$ photoperiod, $70 \%$ relative humidity, $4.97 \mathrm{~m} \mathrm{~s}-1$ wind speed. The experimental design was a randomized complete block design with 3 replicates, the block area $100 \mathrm{~cm} \times 100 \mathrm{~cm}$. After 25 days, the plants were treated with $50 \%, 100 \%, 200 \%$ and $300 \%$ FRD of nominee. The herbicide applications were made using sprayer. Nitrogenfertilizer was applied as urea one week before herbicide application. The herbicide was applied as recommended by the manufacturer

\section{Harvesting of the plant material}

After Seven days of treatment with herbicide, plant leaves (the second leaf from the top) from 3 replicates of each treatment were collected at 10 AM. Frozen immediately in liquid nitrogen and stored at $-80^{\circ} \mathrm{C}$ until used for subsequent biochemical and molecular analyses. 


\section{Biomass yield}

Determination of fresh and dry weights and water contents: The fresh weight, dry weight and water content were determined as described in preliminary.

\section{Biochemical analysis}

Estimation of photosynthetic pigments

It was done according to the method described by Wellburn \& Lichtenthaler (1984).

Determination of anthocyanins (1980).

According to the method adopted by Hoagland

Determination of protein content

The protein content of fresh plant material was measured according to the method of Bradford (1976).

\section{Molecular analysis \\ Quantification of gene expression \\ Quantification of gene expression by semi-quantitative RT-PCR: Total RNA was extracted from about $50 \mathrm{mg}$ frozen leaves using TRI-reagent (Sigma, UK) according to the manufacture's protocol. To prevent DNA contamination, the extracted RNA was treated with DNA-free kit (Ambion, UK) for $30 \mathrm{~min}$}

at $37^{\circ} \mathrm{C}$. Poly A tail mRNA was then isolated by reacting 1011 of RNA with $2 \mu$ of oligo dT(18) and $3 \mu \mathrm{l}$ RNase and DNase free $\mathrm{H}_{2} \mathrm{O}$ for $5 \mathrm{~min}$ at $70^{\circ} \mathrm{C}$ and the reaction was terminated on ice for $2 \mathrm{~min}$. The reverse transcription was conducted by using MMLV-reverse transcription kit according to the supplier's recommendations (Promega, UK). Primers for gene were designed to recognise conserved regions resulting from the alignment of the characterized gene in $E$. colona. The primers used for amplifying ALS and $18 \mathrm{~S}$ rRNA are listed in Table 1. The PCR conditions were as follows: Initial denaturation at $94^{\circ} \mathrm{C}$ for $3 \mathrm{~min}$, followed by 35 and 45 cycles of denaturation at $94^{\circ} \mathrm{C}$ for $30 \mathrm{sec}$, annealing at $50^{\circ} \mathrm{C}$ for $30 \mathrm{sec}$ and extension at $72^{\circ} \mathrm{C}$ for 50 sec, the number of PCR cycles was optimized to show the maximal differences among samples within the linear phase of amplification. PCR products were resolved by electrophoresis on $1 \%$ agarose gels, stained with ethidium bromide in $1 \mathrm{X}$ TAE (Tris-acetic acid-EDTA) using Bio- Rad equipment and visualized and documented using Trans illuminator UViTec. The band volumes were measured by using Lab Image V 2.7.2 software. The measurement was normalized for equal $18 \mathrm{~S}$ rRNA bands.

TABLE 1. Primer pairs used for amplification of ALS, primer pairs were designed according to the DNA sequence for the identified genes from E. crus-galli,E. phyllopogon and Oryza sativa to the data from: http://www. ncbi.nlm.nih.gov.

Amplified

Serial no.

Forward primer $5 ` 3$

Reverse primer 5' 3

fragment size (bp)

Primer I GAACACGCCCATGAGTCTG GGTACGGCCCTGGAGTCTCG $\mathbf{1 1 0 5}$

\section{Statistical analysis}

Each measurement was repeated until consistent results were obtained with at least three independent measurements. In order to compare between samples one way ANOVALSD was performed using SPSS 18.0. and CoStat 6.311 (Carver \& Nash, 2011).

\section{Results}

First experiment

Effect of herbicide on plant growth( E. crus-galli and E. colona)

The negative effect of herbicide on the fresh and dry weights of plants increased by increasing the concentration compared to the control. The Fresh weight was decreased by $75.7 \%, 93.87 \%$ and $96.5 \%$, respectively at $50 \%, 100 \%$ and $200 \%$ in E.crus-galli and also in E.colona it decreased by $75 \%, 84 \%$ and $84.9 \%$, respectively. The Dry weight also decreased by $78 \%, 86.3 \%$ and $90 \%$, respectively at $50 \%, 100 \%$ and $200 \%$ in E.crus-galli and in E.colona it decreased by $75.5 \%, 71 \%$ and $70.6 \%$, respectively (Fig. 1 and Fig. 2). 
(A)

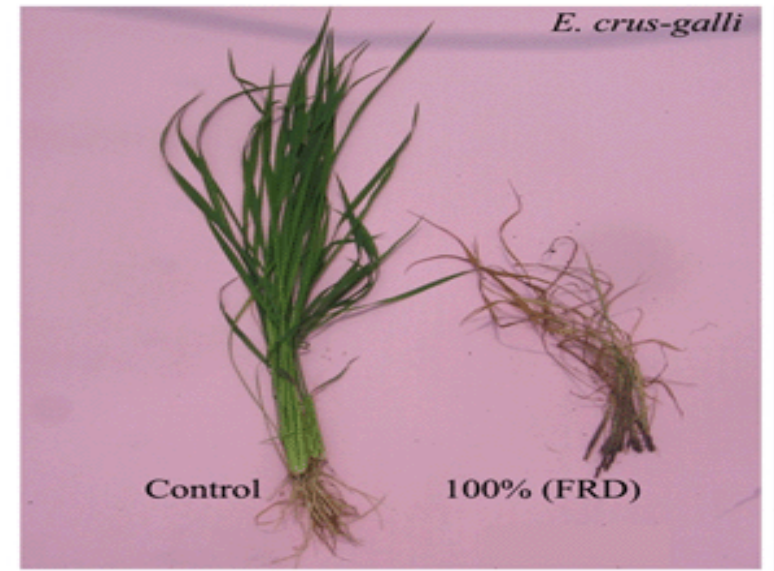

(B)

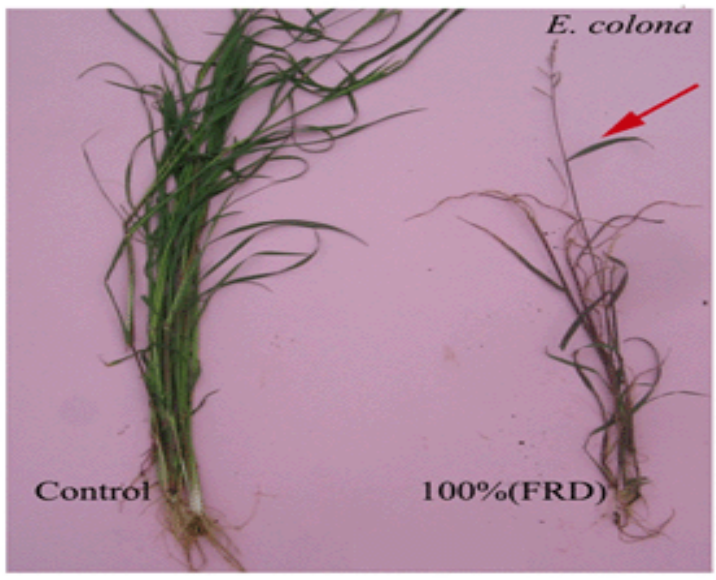

Fig. 1. Effect of Nominee (100\% FRD) on the growth of E. crus-galli (A) and E. colona (B). Young leaf ( $\rightarrow$ )

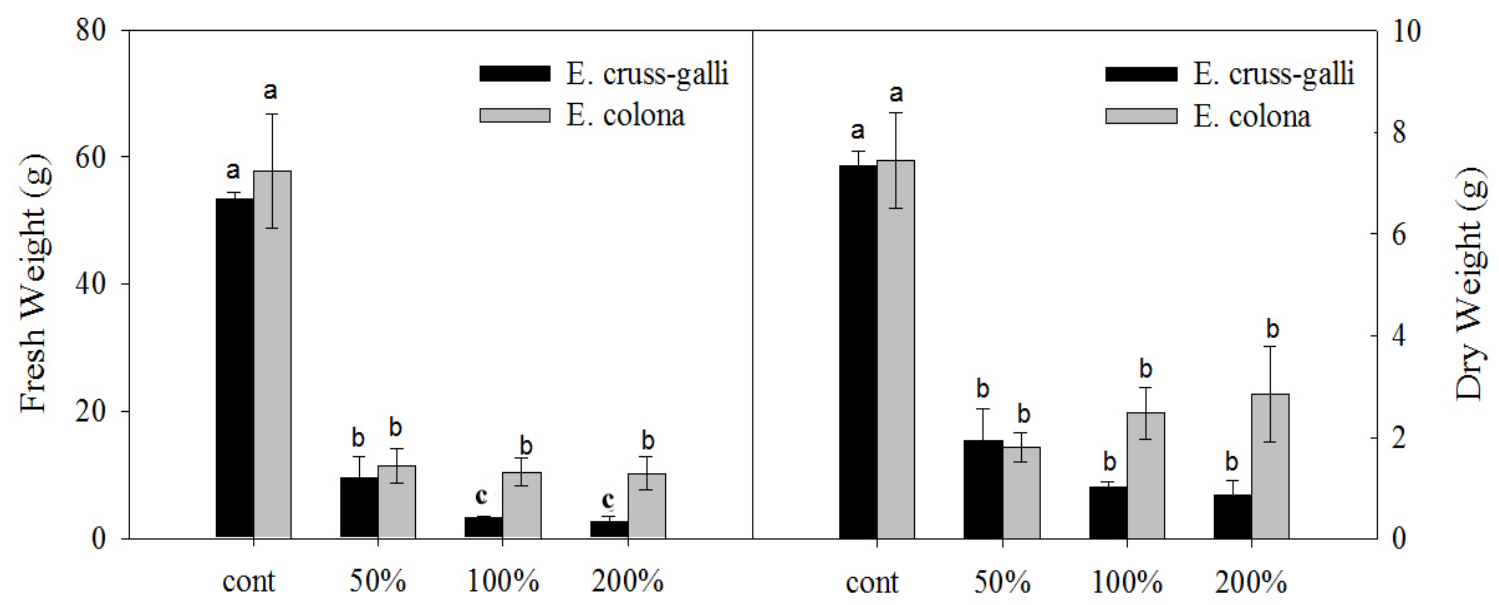

Herbicide concentration

Herbicide concentration

Fig.2. Effects of Nominee (50\%, $100 \%$ and $200 \%$ FRD) on fresh weight and dry weight of $E$. crus-galli and $E$. colona. Bars are means \pm SE. Bars labeled with different letters are significantly different at $\mathbf{p}<\mathbf{0 . 0 5}$.

Second experiment

Resistance of E. colona to Nominee

Biomass yield (fresh weight, dry weight and water content): The fresh and the dry weight was decreased by increasing the concentration of the applied herbicide compared to the control. Fresh weight was decreased by increasing the concentration of herbicide, at $50 \%, 100 \%$, $200 \%$ and $300 \%$ by $80 \%, 90 \%, 90 \%$ and $92 \%$, respectively (Fig. 3 and Fig. 4 A).

Dry weight was decreased by increasing the concentration at $50 \%, 100 \%, 200 \%$ and $300 \%$ by $67.8 \%, 80.2 \%, 81.3 \%$ and $81.9 \%$, respectively. Water content was slightly variable at different herbicide concentrations, it was decreased compared to the control by increasing the concentration of herbicide at $50 \%, 100 \%, 200 \%$ and $300 \%$ by $7.8 \%, 11.9 \%$, $10 \%$ and $16.8 \%$, respectively (Fig. 4 B \& C).

\section{Physiological parameters}

Photosynthetic pigments: Chlorophyll a was decreased by $25.5 \%, 36.6 \%, 43.8 \%$ and $67.4 \%$, respectively at $50 \%, 100 \%, 200 \%$ and $300 \%$, also carotenoids were decreased by $24 \%, 40 \%, 41.3$ and $65.5 \%$, respectively at $50 \%, 100 \%, 200 \%$ and $300 \%$, but chlorophyll b was increased at $50 \%$ compared to the control then decreased by increasing the concentration up to $200 \%$ (Table 2 ). 


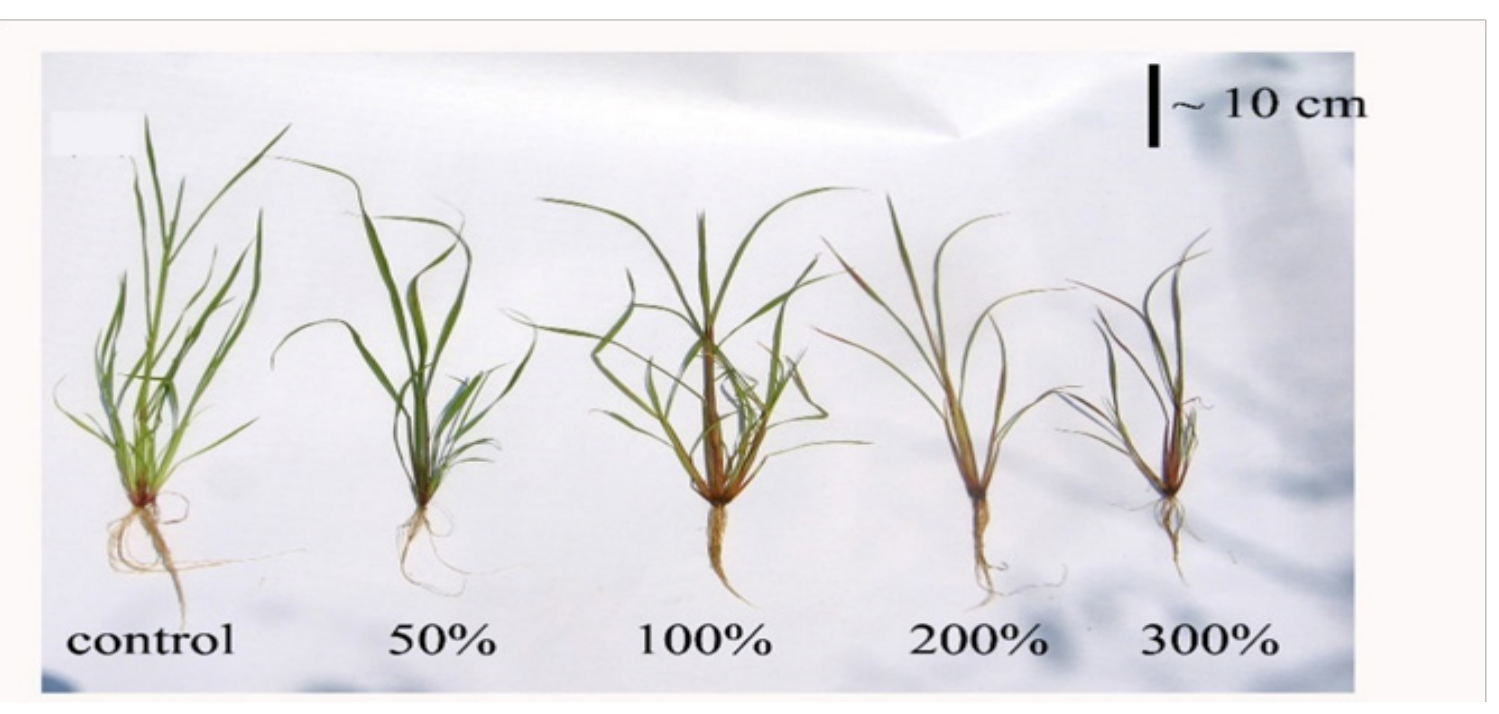

Fig.3. Effects of Nominee $(50 \%, 100 \%, 200 \%$ and $300 \%$ FRD) on growth of $E$. colona, bar $=10 \mathrm{~cm}$.

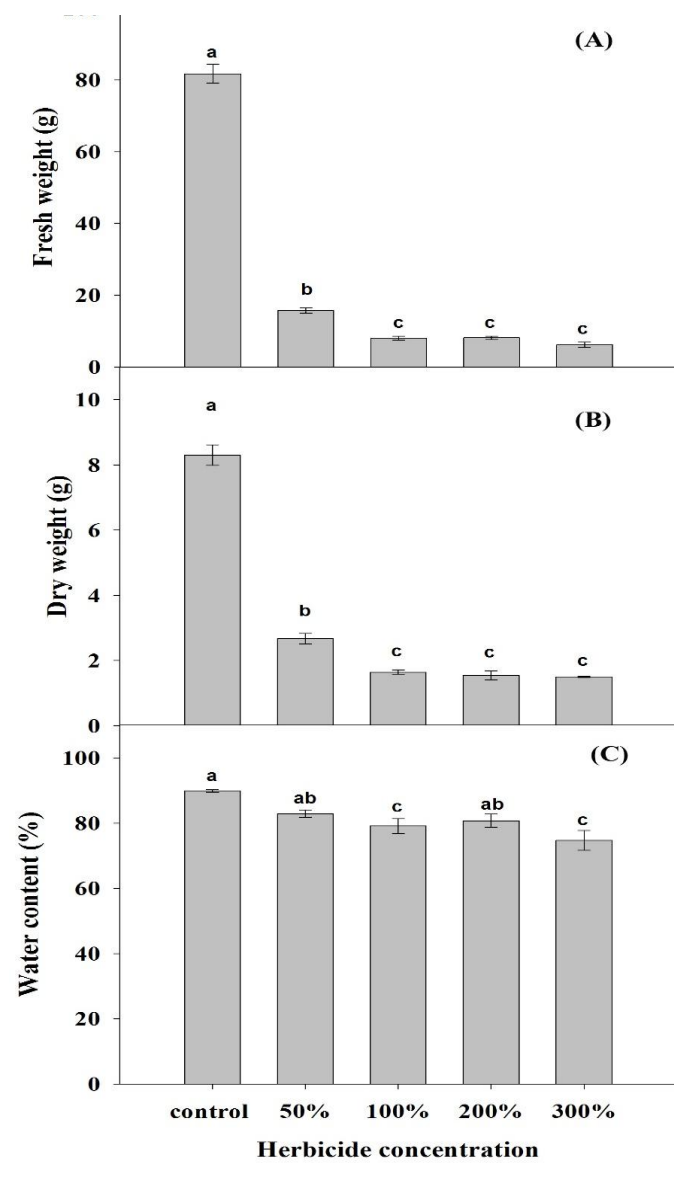

Fig. 4. Effects of Nominee $(50 \%, 100 \%, 200 \%$ and $300 \%$ FRD) on fresh weight, dry weight and water content of $E$. colona. Data is mean \pm SE. Bars labeled with different letters are significantly different at $\mathbf{P}<\mathbf{0 . 0 5}$.
Anthocyanins: The anthocyanins content were increased in comparing to the control by increasing the herbicide concentration, they were increased by $60.8 \%, 2$ folds and 2.7 folds, respectively at 100\%, 200\% and 300\% (Fig. 5).

Soluble and insoluble sugars : Both soluble and insoluble sugars content were affected according to the herbicide concentration. soluble sugars were increased compared to the control at $50 \%, 100 \%, 200 \%$ and $300 \%$ by $65.78 \%, 2.5$ folds, 3 folds and 2.8 folds, respectively and insoluble sugars were increased at $100 \%, 200 \%$ and $300 \%$ by $36.7 \%$, $72.2 \%$ and $18.5 \%$, respectively. (Table 2 ).

Protein content: Protein content was affected with herbicide concentration, it significantly decreased by $18.4 \%$ at $300 \%$ FRD (Table 2).

Expression of acetolactate synthase (ALS) genein response to Nominee treatments.

The transcript level of $A L S$ in E. colona was modified by different concentrations of nominee. In absence of rice 7 days after treatment, it increased at $50 \%$ by 4 folds, then decreased at $100 \%$ by $93.7 \%$, and was not detected in $200 \%$ and $300 \%$ (Fig.6). 
TABLE 2 . The effects of Nominee (50\%, 100\%, $200 \%$ and $300 \%$ FRD) on chlorophyll A, chlorophyll B, carotenoid, soluble sugar, insoluble sugar and protein content of $E$. colona Data is mean $\pm \mathrm{SE}$. datain a column with different letters are significantly different at $\mathrm{P}<0.05$.

\begin{tabular}{lcccccc}
\hline \multirow{2}{*}{ Treatment } & \multicolumn{5}{c}{ Physiological parameters } \\
\cline { 2 - 6 } & Chloro. A & Chloro. B & Carotenoids & Sol. sugar & Insol. sugar & Protein \\
\hline Cont. & $1.3 \pm 0.06^{\mathrm{a}}$ & $0.55 \pm 0.09$ & $0.4 \pm 0.007^{\mathrm{a}}$ & $0.04 \pm 0.002^{\mathrm{d}}$ & $0.31 \pm .003^{\mathrm{c}}$ & $5.9 \pm 0.07^{\mathrm{d}}$ \\
$50 \%$ & $1.1 \pm 0.007^{\mathrm{a}}$ & $0.61 \pm 0.02$ & $0.35 \pm 0.03^{\mathrm{ab}}$ & $0.14 \pm .001^{\mathrm{b}}$ & $0.35 \pm .002^{\mathrm{b}}$ & $7.9 \pm 0.19^{\mathrm{bc}}$ \\
$100 \%$ & $0.7 \pm 0.01^{\mathrm{b}}$ & $0.43 \pm 0.01$ & $0.3 \pm 0.009^{\mathrm{bc}}$ & $0.23 \pm .004^{\mathrm{a}}$ & $0.37 \pm .005^{\mathrm{a}}$ & $8.8 \pm 0.15^{\mathrm{ab}}$ \\
$200 \%$ & $0.56 \pm 0.04^{\mathrm{bc}}$ & $0.37 \pm 0.03$ & $0.24 \pm 0.005^{\mathrm{cd}}$ & $0.24 \pm .003^{\mathrm{a}}$ & $0.38 \pm .001^{\mathrm{a}}$ & $9.7 \pm 0.32^{\mathrm{a}}$ \\
$300 \%$ & $0.18 \pm 0.02^{\mathrm{c}}$ & $0.07 \pm 0.002$ & $0.17 \pm 0.002^{\mathrm{e}}$ & $0.11 \pm .004^{\mathrm{c}}$ & $0.32 \pm .003^{\mathrm{c}}$ & $7.18 \pm 0.23^{\mathrm{cd}}$ \\
$\mathrm{F}$ & $94.384^{* * *}$ & 12.559 & $45.747^{* * *}$ & $670.229^{* * *}$ & $92.209^{* * *}$ & $47.48^{* * *}$ \\
\hline
\end{tabular}

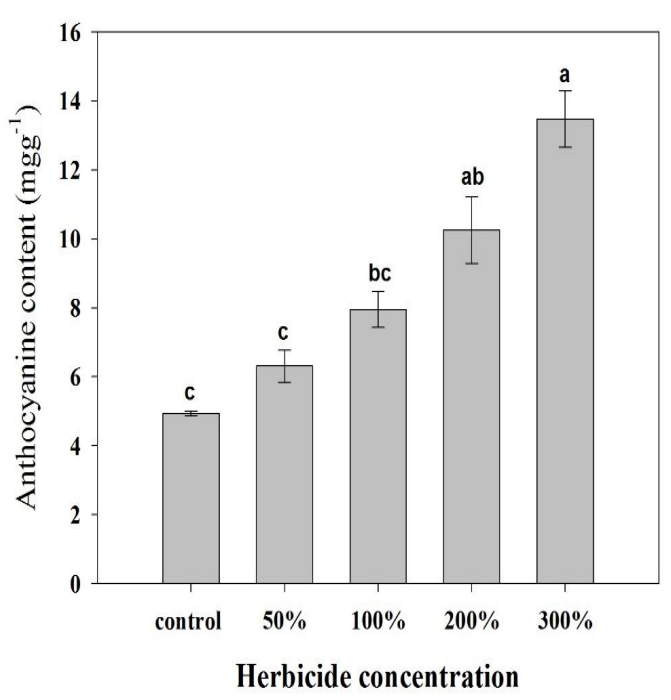

Fig.5. Effects of Nominee $(50 \%, 100 \%, 200 \%$ and $300 \%$ FRD) on anthocyanins content of $E$. colona. Data is mean $\pm \mathrm{SE}$. Bars labeled with different letters are significantly different at $\mathbf{P}<\mathbf{0 . 0 5}$.

\section{Discussion}

Herbicides have been used to enhance the productivity of crops by killing the weeds which compete with the growth of cultivated plants. In the present study, Nominee ${ }^{\mathrm{tm}}$ (bispyribac-sodium) was applied as herbicide and plant responses was studied on E. crus-galli and E. colona. A preliminary experiment indicated that the growth of E. crusgalli in terms of fresh and dry weight was reduced by $93.87 \%$ and $86.3 \%$, respectively at $100 \%$ FRD. While E. colona growth in terms of fresh and dry weight was decreased at $100 \%$ FRD by $84 \%$ and $71 \%$, respectively, but nonetheless, the plants were still growing and young leaves were present (Fig. 1). Different responses to bispyribac-sodium were reported by Riar et al. (2012), who found that three Echinochloa crus-galli populations from rice fields in Arkansas (AR1 and AR2) and Mississippi (MS1) showed different responses, reduction in dry weight of AR2 was 99\% (susceptible population), in resistant populations, the dry weight reduction was from $54 \%$ to $62 \%$ and from $71 \%$ to $73 \%$ in AR1 and MS1 populations, respectively. Kaloumenos et al. (2013) also indicated that bispyribac-sodium applied at the recommended rate reduced the fresh weight of nine susceptible E. oryzicola accessions by 83 $100 \%$. The present results suggest that E. crus-galli was susceptible to bispyribac-sodium but $E$. colona showed some resistance.

Investigation of the resistance of E. colona to Nominee

The dose response studies on plants treated with bispyribac-sodium confirmed that $E$. colona was resistant. Although the herbicide effect on the biomass of plants which caused reduction in fresh and dry. The fresh and dry weight of E. colona, was decreased by increasing herbicide concentration from $50 \%$ to $300 \%$ FRD (Fig. 3 and 4). Kaloumenos et al. (2013) reported that bispyribac-sodium applied at the recommended rate reduced the fresh weight of six $E$. oryzicola accessions by $63-77 \%$. These accessions were labelled 'less Susceptible' and applied at 4 times the recommended rate reduced the fresh weight of two E. oryzicola accessions only by $16-33 \%$ and 12 $31 \%$ respectively and these accessions were labeled 'Resistant'. Based on the present results, E. colona can be considered susceptible (fresh weight decreased by $>80 \%$ ). 
(A)

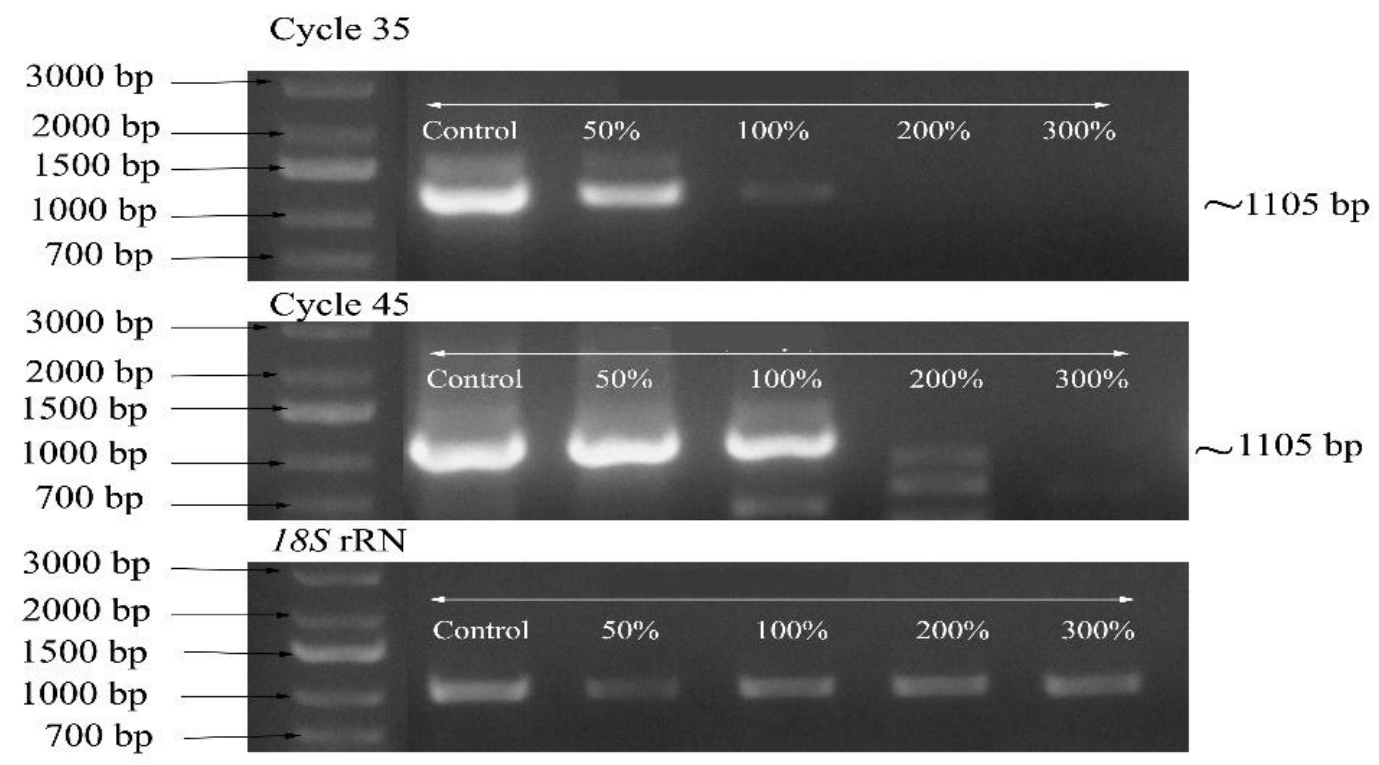

(B)

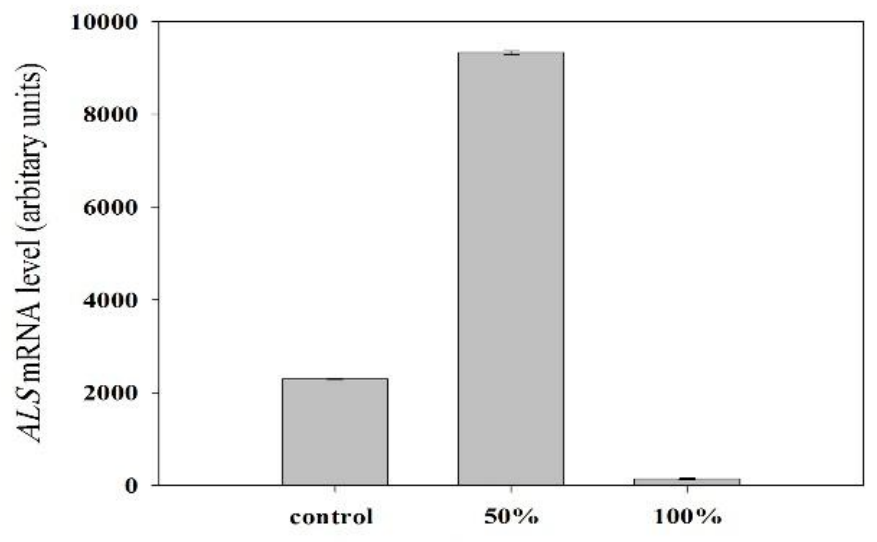

Herbicide concentration

Fig. 6. Semi-quantitative RT-PCR of $E$. colona ALS under different concentrations of Nominee $(50 \%, 100 \%$, $200 \%$ and $300 \%$ FRD). (A): Ethidium bromide-stained gels after different cycles showing the growth of the bands at cycle 35 and at cycle 45 (saturated cycle). (B): Quantification of expression in terms of band volumes at cycle 35 .

The photosynthetic pigments were affected by herbicide, where the chlorophyll a, chlorophyll $\mathrm{b}$ and carotenoide content was decreased by increasing the herbicide concentration from 1000 to $300 \%$ FRD (Table 2). Reduction in chlorophyll content may be due to its incorporation into the cell membrane function through physiological processes, such as depolarization of membrane potential (Wright, 1994). Reduction also might be due to the enhanced activity of chlorophyll degrading enzyme chlorophyllase and/or disruption of the fine structure of chloroplast and instability of chloroplast or pigment-protein complex, which leads to oxidation of chlorophyll and decreased its concentration (Hamza et al., 2012).

The anthocyanins content were increased by increasing the herbicide concentration from 100 to $300 \%$ FRD (Table 2). E. colona have anthocyanine pigment in leaves through their life span, or else they are induced and retained only after the plant has experienced stress (Chalker- 
Scott, 1999). The function of anthocyanins in leaves is the photoprotection of chloroplasts; under saturated light, anthocyanins potentially mitigate photoinhibitory and photo-oxidative damage by absorbing a proportion of the photons surplus to the requirements of the light reactions of photosynthesis (Esteban et al., 2008 and Zeliou et al., 2009). This may be the case in the present study where, herbicide affects photosynthetic pigmentation which decreases. So anthocyanine pigments increased to protect the leaves from the stress of photoinhibitory light fluxes by absorbing the excess photons.

The soluble and insoluble sugar content was increased by increasing the concentration from 50 to $300 \%$ FRD (Table 2). Carbohydrate accumulation in leaves has been repeatedly reported after treatment with ALS inhibitors (Wittenbach \& Abell, 1999). Zabalza et al. (2004) reported that decrease in sink strength seems to cause the carbohydrate accumulation in leaves. Plants with lowered sink strength (tuber excised) accumulated carbohydrate in the leaves and displayed a considerably reduced maximum photosynthetic rate (Basu et al., 1999). This agrees with the present results where accumulation of carbohydrates in leaves attached coincided with a decrease in plant growth rate.

The protein content was increased by increasing the concentration from 50 to $200 \%$ FRD then decreased by $18.4 \%$ at $300 \%$ FRD. Several biochemical and physiological effects have been described as a secondary consequence of the primary action of $A L S$ inhibitors like decrease in protein levels (Sidari et al., 1998). It could propose that an increase in the protein content was detected because it measured in young leaves that may have been produced after application of herbicide. This view agrees with Rhodes et al. (1987) who suggested that decline in protein content was caused by an increase in the protein turnover.

\section{Expression of acetolactate synthase (ALS)}

The transcript level of $A L S$ in E. colona was modified by different concentrations of bispyricsodium (nominee), it increased at $50 \%$, then decreased at $100 \%$, and was not detected in $200 \%$ and $300 \%$ FRD. The present study indicated that $A L S$ expression level was responsive to herbicide treatment. This suggests that $A L S$ is a target site of bispyric-sodium. But 50\% FRD can be considered as sub-lethal dose which upregulated the expression of $A L S$ by 4 folds. Often, evolved $A L S$ herbicide resistance in plants is target-site $A L S$ based, endowed by one or more specific resistance-endowing point mutations in the $A L S$ gene. Generally, $A L S$ resistance mutations at Pro-197 confer SU and TP resistance, mutations at Ala-122, Ala-205, Ser-653 or Gly-654 confer IMI resistance, and mutations at Asp-376, Arg-377 or Trp-574 confer broad spectrum resistance across $A L S$ herbicides (Yu et al., 2012). So in the present results the resistance of E. colona to bispyric-sodium might be due to mutation in one of these points on $A L S$ gene. Kaloumenos et al. (2013) reported that the sequence alignment comparison between the susceptible E. crus-galli and resistant E. oryzicolaand putative resistant E. oryzicola accessions revealed a heterozygous mutation in resistant and putative resistant accessions at the second nucleotide of codon 574. The presence of Trp574Leu mutation in the 12 analysed E. oryzicola $A L S$ sequences from resistante $E$. oryzicola supports the evidence that cross resistance to ALS-inhibiting herbicides was due to mutant $A L S$ alleles encoding an amino-acid replacement at codon 574. So the resistance of E. colona to bispyric-sodium could be due to presence of Trp574Leu mutation.

\section{References}

Basu, P.S., Sharma, A., Garg, I.D. and Sukumaran, N.P. (1999) Tuber sink modifies photosynthetic response in potato under water stress. Environmental and Experimental Botany, 42, 25-29.

Bradford, M.M. (1976) A rapid and sensitive method for the quantitation of microgram quantities of protein utilizing the principle of protein-dye binding. Analatical Biochemistry, 72, 248-254.

Busi, R., Vidotto, F., Tabacchi, M. and Ferrero, A. (2002) A preliminary study on propanil-resistant Echinochloa crus-galli in north-west Italy rice fields. In: VII Congress of European Society for Agronomy, Cordoba, Spain, pp. 173-174.

Carver, R.H. and Nash, J.G. (2011) Doing data analysis with SPSS version 18, Cengage Learning

Chalker-Scott, L. (1999) Environmental significance of anthocyanins in plant stress responses. Photochem Photobiol, 70(1), 1-9.

Esteban, R., Ferna' ndez-Marı'n, B., Becerril, J.M. and Garci'a-Plazaola, J.I. (2008) Photoprotective implications of leaf variegation in E. dens-canis L. and P. officinalis L. Journal of Plant Physiology, 165, 1255-1263.

Fischer, A.J., Bayer, D.E., Carriere, M.D., Ateh, C.M. and Yim, K.O. (2000) Mechanisms of resistance to bispyribac-sodium in an Echinochloa phyllopogon accession. Pestic. Biochem. Physiol. 68, 156-165. 
Gibson, K.D., Fischer, A.J., Foin, T.C. and Hill, J.E. (2003) Implications of delayed Echinochloa germination and duration of competition for integrated weed management in water-seeded rice. Weed Research, 51, 87-93.

Hamza, A., Derbalah, A. and El-Nady, M. (2012) Identification and mechanism of Echinochloa crusgalli resistance to fenoxaprop-p-ethyl with respect to physiological and anatomical differences. The Scientific World Journal, Article ID 893204, 8 pages.

Heap, I.M. (2011) International survey of herbicide resistant weeds. Available at: http://www. weedscience.org (last accessed 25 August 2011).

Hoagland, R.E., Norsworthy, J.K., Carey, F. and Talbert, R.E. (2004) Metabolically based resistance to the herbicide propanil in Echinochloa species. Weed Science, 52, 475-486.

Hoagland, R.E. (1980) Effect of glyphorate on metabolism of phenolic compounds. Weeds SCi, 28, 393-400.

Holm, L.G., Plucknett, D.L., Pancho, J.V. and Herberger, J.P. (1977) Echinochloa crus-galli (L.) Beauv. In: "The World's Worst Weeds", 32- 40 pp. Honolulu, HI, USA: University Press of Hawaii.

Holm, L.G., Plucknett, D.L., Pancho, J.V. and Herberger, J.P. (1991) "The World's Worst Weeds: Distribution and Biology", 609-612 pp. Malabar, Florida: The University Press of Hawaii.

Kaloumenos, N.S., Chatzilazaridou, S.L., Mylona, P.V., Polidorosd, A.N. and Eleftherohorinosb, I.G. (2013) Target-site mutation associated with cross-resistance to ALS-inhibiting herbicides in late watergrass (Echinochloaoryzicola Vasing.). Pest Manag. Sci. 69, 865-873.

Kawai, K., Kaku, K., Izawa, N., Shimizu, T., Fukuda, A. and Tanaka, Y. (2007) A novel mutant acetolactate synthase gene from rice cells, which confers resistance to ALS-inhibiting herbicides. J. Pestic. Sci. 32, 89-98.

Okuzaki, A., Shimizu, T., Kaku, K., Kawai, K. and Toriyama, K. (2007) A novel mutated acetolactate synthase gene conferring specific resistance to pyrimidinylcarboxy herbicides in rice. Plant Mol. Biol. 64, 219-224.

Rao, A.N., Johnson, D.E., Sivaprasad, B., Ladha, J.K. and Mortimer, A.M. (2007) Weed management in directseeded rice. Adv. Agron. 93, 153-255.

Rhodes, O., Hogan, A.L., Deal, L., Jamieson, G.C. and Haworth, P. (1987) Amino acid metabolism of Lemna minor L. II. Responses to chlorsulfuron. Plant
Physiol. 84, 775-780.

Riar, D.S., Norsworthy, J.K., Bond, J.A., Bararpour, M.T.,Wilson, M.J. and Scott, R.C. (2012) Resistance of Echinochloa crus-galli populations to acetolactate synthase - inhibiting herbicides. International Journal of Agronomy, Article ID 893953:1-8.

Sidari , M., Pusino, A., Gessa, C. and Cacco, G. (1998) Effect of imazamethabenz- methyl on nitrate uptake in wheat (Triticum durum L.). J. Agric. Food Chem. 46, 2800-2803.

Tranel, P.J. and Wright, T.R. (2002) Resistance of weeds to ALS inhibiting herbicides: What have we learned? Weed Sci. 50, 700-712.

Tranel, P.J., Wright, T.R. and Heap, I.M. (2012) ALS mutations from herbicide-resistant weeds. Available at: http:// www.weedscience.com.

Wellburn, A.R. and Lichtenthaler, H. (1984) In: "Advances in Photosynthesis Research" Sybesma (Ed.), Vol. II, pp. 9-12, Martinus Nijhoff, Co., The Hague.

Wittenbach, V.A. and Abell, L.M. (1999) Inhibitors of valine, leucine and isoleucine biosynthesis. In: "Plant Amino Acids: Biochemistry and Biotechnology" Singh, B.K. (Ed.), 385-416 pp. Marcel Dekker, New York.

Wright, J.P. (1994) Use of membrane potential measurements to study mode of action of diclofopmethyl. Weed Science, 42, 285-292.

Yu, Q., Han, H., Li, M., Purba, E., Walsh, M.J. and Powles, S.B. (2012) Resistance evaluation for herbicide resistance- endowing acetolactate synthase (ALS) gene mutations using Raphanus raphanistrum populations homozygous for specific ALS mutations. European Weed Research Society Weed Research, 52, 178-186.

Zabalza, A., Orcaray, L., Gaston, S. and Royuela, M. (2004) Carbohydrate accumulation in leaves of plants treated with the herbicide Chlorsulfuron or Imazethapyr is due to a decrease in dink strength. $J$. Agric. Food Chem. 52, 7601-7606.

Zeliou, K., Manetas, Y. and Petropoulou, Y. (2009) Transient winter leaf reddening in Cistus creticus characterizes weak (stress-sensitive) individuals, yet anthocyanins cannot alleviate the adverse effects on photosynthesis. Journal of Experimental Botany, 60, 3031-3042.

(Received 2 / 8 / 2017; accepted $11 / 1 / 2018$ ) 


\section{الإستجابات المختلفة لنباتى الانيبه و أبوركبه ل لمبيد النومينى}

عبد العميد خضر، ممدوح سراج ، هبة شعبان و جابر أبوجادالله

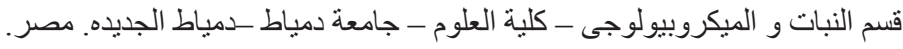

يعتبر نباتى الدنيبه و أبوركبه من الحشائش الضارة المؤثرة على نمو و إنتاجية بعض المحاصيل الإقتصاديه

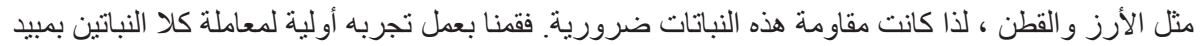

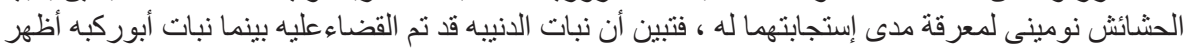

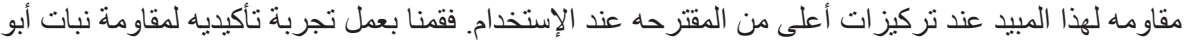

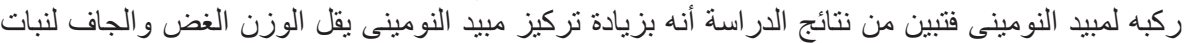

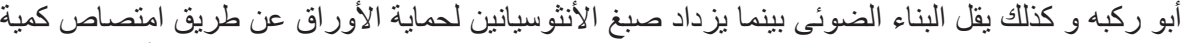

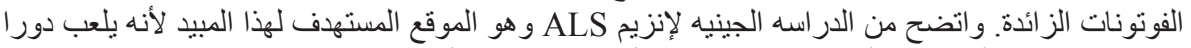

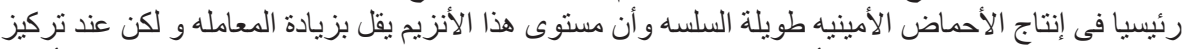
05\% من التركيز المقترح تبين أن هذا التركيز يعتبر جر عه غيل هير ميته محفزة لإنتاج الإنزيم بمقدار أربعة 